\title{
Evidence that the onset of seasonal anoestrus in the ewe may be independent of increasing prolactin concentrations and daylength
}

\author{
Karen Worthy and W. Haresign \\ Department of Agriculture and Horticulture, University of Nottingham, School of Agriculture, \\ Sutton Bonington, Loughborough, Leicestershire LE12 5RD, U.K.
}

\begin{abstract}
Summary. Nine ewes of each of two breeds, Dorset Horn (long breeding season) and Welsh Mountain (short breeding season), were ovariectomized after insertion of subcutaneous implants containing oestradiol-17 $\beta$. A further 9 ewes of each breed were left entire. All of the ewes were placed in an artificial photoperiod of $8 \mathrm{~L}: 16 \mathrm{D}$ on 12 December 1980. After 5 weeks half of the ewes of each breed and physiological state were abruptly changed into a long-day photoperiod $(16 \mathrm{~L}: 8 \mathrm{D})$ while the rest remained in short days. The time of onset of seasonal anoestrus in entire animals was significantly advanced in ewes changed to long days, with the end of the breeding season coming at the normal time of year in ewes maintained in short days. These differences in oestrous cycle activity were reflected by differences in the time at which LH concentrations in ovariectomized, oestrogen-treated ewes on the two light treatments fell to basal values. Prolactin concentrations showed an immediate and sustained rise in ewes changed to long days, but remained low in ewes maintained in short days. Since the onset of seasonal anoestrus occurred in the absence of high levels of prolactin (in short-day ewes), it is concluded that prolactin is not the major vehicle by which seasonal changes in hypothalamic responsiveness to the negative feedback effects of oestradiol are produced. The results suggest that anoestrus may be due to photorefractoriness.
\end{abstract}

\section{Introduction}

In recent years, insight has been gained into the mechanisms governing seasonal breeding in the ewe. It has been shown (Legan, Karsch \& Foster, 1977) that marked seasonal fluctuations in LH concentrations occur in ovariectomized, oestrogen-treated ewes, despite the constant levels of plasma oestradiol maintained by subcutaneous oestradiol implants. This observation suggests that there might be a seasonal change in responsiveness of the hypothalamic-pituitary axis to the negative feedback effects of oestradiol; LH secretion and cyclic activity are inhibited during seasonal anoestrus with a reversal of these events at the beginning of the breeding season. The hypothesis is an attractive one because the seasonal rise and fall of $\mathbf{L H}$ concentrations in ovariectomized, oestrogen-treated ewes is synchronous with the onset and end of the breeding season in entire ewes (Legan et al., 1977).

One element lacking in this model, however, is an explanation of how seasonal changes in negative feedback responsiveness are brought about. Daylength is known to be the principal environmental factor dictating the timing of seasonal breeding in the ewe (Yeates, 1949), and Legan \& Karsch (1980) have shown that LH changes in ovariectomized, oestrogen-treated ewes 
kept in 90-day cycles of long and short days are closely dictated by the photoperiodic environment. Attempts have therefore been made to establish whether some other hormone responding to daylength could mediate the effects of photoperiod on the responsiveness of the hypothalamicpituitary axis to the negative feedback effects of oestradiol. Prolactin appears to be a primary candidate for this role since prolactin concentrations in sheep show very marked seasonal fluctuations in concert with daylength, being high during long days (corresponding with seasonal anoestrus) and low during short days (breeding season) (Walton, McNeilly, McNeilly \& Cunningham, 1977; Carr \& Land, 1982; Webster \& Haresign, 1983). A clear-cut physiological role for prolactin in the ewe has yet to be established, although high concentrations have been implicated as the cause of lactational anoestrus in this species (Kann \& Martinet, 1975). Furthermore, when groups of rams were reared and maintained in constant long days or natural photoperiod for approximately 3 years the testis growth phase was always preceded by a fall in plasma prolactin concentrations (Howles, Craigon \& Haynes, 1982). Evidence also exists for antigonadotrophic effects of high prolactin concentrations in women (see McNeilly, 1980), rats (Fang, Refetoff \& Rosenfield, 1974; McNeilly, Sharpe, Davidson \& Fraser, 1978) and birds (Camper \& Burke, 1977). Together, these observations suggest that prolactin might mediate seasonal changes in hypothalamic responsiveness to steroid negative feedback, and this is supported by the observation of a similar change in responsiveness to oestradiol in post-partum ewes (Wright, Geytenbeek, Clarke \& Findlay, 1981a).

Webster \& Haresign (1983) examined seasonal changes in LH and prolactin levels in ewes of two breeds under natural daylength conditions. Breeds with very different seasonal characteristics were chosen in the hope that differences in hormonal responses between them might explain the dissimilarities in their reproductive behaviour. Although the breeds came into oestrus at different times of the year, temporal changes in prolactin were identical. This suggests that prolactin is not involved in the control of seasonal breeding, or that the breeds have very different sensitivities to prolactin concentrations, at least at the beginning of the breeding season. The present experiment was designed to investigate further, by means of photoperiodic manipulation, the possible role of prolactin in controlling the onset of seasonal anoestrus in the ewe.

\section{Materials and Methods}

\section{Animals and experimental design}

Mature Dorset Horn ewes (breeding season 8-9 months) and Welsh Mountain ewes (breeding season 4-5 months) were used, and were largely the same animals used in the experiment of Webster \& Haresign (1983). Immediately before ovariectomy, 9 ewes of each breed had been given a subcutaneous oestradiol implant, of a type designed to maintain plasma oestradiol levels of 3-5 $\mathrm{pg} / \mathrm{ml}$ (Karsch et al., 1973). The remaining ewes ( 9 per breed) were left entire and did not receive oestradiol implants. On 12 December, before the winter solstice, the ewes were housed in a lightproof building with an artificial photoperiod similar to that prevailing outside, of $8 \mathrm{~h}$ light and $16 \mathrm{~h}$ dark $(8 \mathrm{~L}: 16 \mathrm{D})$.

After 5 weeks, half of the ewes of each breed and physiological state were abruptly exposed to a long-day photoperiod $(16 \mathrm{~L}: 8 \mathrm{D})$, while the rest of the animals remained in short days $(8 \mathrm{~L}: 16 \mathrm{D})$, such that there were 4 or 5 ewes representing each breed/physiological state combination in each light treatment. The animals were then maintained in these two photoperiods for a further 20 weeks. Artificial control of house temperature and humidity were not possible, and these fluctuated in accord with outside conditions. The lights were controlled automatically using an electronic timer, and light intensities at sheep head height were 85 and $<1$ lux during the light and dark phases respectively. All ewes were fed a maintenance diet of indoor sheep concentrates and hay, with permanent access to water and mineral licks. Oestrous activity was monitored by using colourmarked vasectomized rams. 
Blood samples were collected by jugular venepuncture during the light phase from all ewes 3 times a week throughout, and the plasma stored at $-20^{\circ} \mathrm{C}$ until required for $\mathrm{LH}$, prolactin and progesterone determinations.

\section{Hormone assays}

Luteinizing hormone. Plasma LH concentrations were measured using the specific doubleantibody radioimmunoassay of Foster \& Crighton (1974) as modified by McLeod, Haresign \& Lamming (1982a) to increase the sensitivity of the assay to $0.3 \mathrm{ng}$ equiv. NIH-LH-S17/ml plasma. The inter- and intra-assay coefficients of variation were $16 \%$ and $10 \%$ respectively, and there was negligible cross-reaction with other protein hormones (ovine prolactin, growth hormone, FSH or TSH).

Prolactin. Plasma prolactin concentrations were determined by the specific double-antibody radioimmunoassay described by Howles, Webster \& Haynes (1980) with the single modification that the first antibody was used at a working dilution of $1: 25000$. The intra-assay coefficient of variation for randomly selected duplicate pairs was $7 \%$; the inter-assay coefficient of variation was $11 \%$ and the limit of sensitivity of the assay (defined as twice the s.d. of blank values) was $1.8 \mathrm{ng}$ equiv. NIH-P-S10/ml plasma. The assay showed negligible cross-reaction with other protein hormones.

Progesterone. Progesterone concentrations were measured by the radioimmunoassay method of Haresign, Foster, Haynes, Crighton \& Lamming (1975). The assay showed negligible crossreaction with other major steroid hormones, the inter- and intra-assay coefficients of variation were both $<10 \%$ and the sensitivity of the assay was $0 \cdot 1 \mathrm{ng} / \mathrm{ml}$ plasma.

\section{Results}

\section{Cyclic activity}

When progesterone concentrations were used to assess the time of cessation of cyclic activity there were no significant differences between the two breeds in the timing of the end of the breeding season for each photoperiod (Table 1). However, there was a highly significant difference between the two photoperiods when the breeds were pooled $(P<0.001$, analysis of variance), with ewes which had been changed to long days becoming anoestrous earlier. Furthermore, the onset of anoestrus was significantly advanced in these animals compared to the expected time of onset under natural daylength conditions. In contrast, the end of the breeding season came at about the normal time in ewes maintained in short days. In addition, the degree of synchrony in the cessation of cyclic activity was much greater for the ewes of both breeds that were switched to long days.

Table 1. Dates of onset of seasonal anoestrus in entire ewes of 2 breeds in relation to the first date of exposure to long days (19 January)

\begin{tabular}{|c|c|c|c|}
\hline & \multicolumn{2}{|c|}{ Days from 19 January to last cycle } & \multirow{2}{*}{$\begin{array}{l}\text { Normal end of } \\
\text { breeding season in } \\
\text { previous year* }\end{array}$} \\
\hline & $16 \mathrm{~L}: 8 \mathrm{D}$ & $8 \mathrm{~L}: 16 \mathrm{D}$ & \\
\hline Dorset Horn & $\begin{array}{c}42.8 \pm 5.7(\mathrm{~N}=5) \\
(3 \mathrm{March})\end{array}$ & $\left.\frac{86.8 \pm 17 \cdot 7(\mathrm{~N}}{(16 \text { April })}=4\right)$ & $\begin{array}{c}3 \text { April } \pm 7.9 \text { days } \\
(\mathbf{N}=10)\end{array}$ \\
\hline Welsh Mountain & $\begin{array}{c}51.8 \pm 3.9(\mathrm{~N}=5) \\
(12 \mathrm{March})\end{array}$ & $\frac{93 \cdot 8 \pm 16 \cdot 1(\mathrm{~N}=4)}{(23 \text { April })}$ & $\begin{array}{c}11 \text { April } \pm 9 \cdot 1 \text { days } \\
(\mathrm{N}=10)\end{array}$ \\
\hline
\end{tabular}

Values are mean \pm s.e.m., for the no. of ewes indicated. The dates in parentheses are the mean date of onset of seasonal anoestrus for each group.

* Data from Webster \& Haresign (1983). 


\section{Prolactin concentrations}

Text-figure 1 shows mean plasma prolactin concentrations for the various treatment groups. In ewes changed to long days, there was an immediate and sustained rise in prolactin concentrations. This rise followed a similar pattern in both breeds, and there was no significant difference between entire and ovariectomized, oestrogen-treated ewes in this respect. The levels of prolactin seen in long-day animals were comparable to those previously measured in the same ewes during the summer months under natural daylength conditions (Webster \& Haresign, 1983).

In ewes maintained in short days, prolactin levels remained low, at concentrations similar to those seen at the beginning of the experiment, although in the Dorset Horn ewes there was a tendency for values to rise towards the end of the experiment.

The effect of daylength on prolactin levels was highly significant $(P<0.001)$ when the data were tested by means of a 4-way analysis of variance, although there were no significant differences between breeds or physiological states.

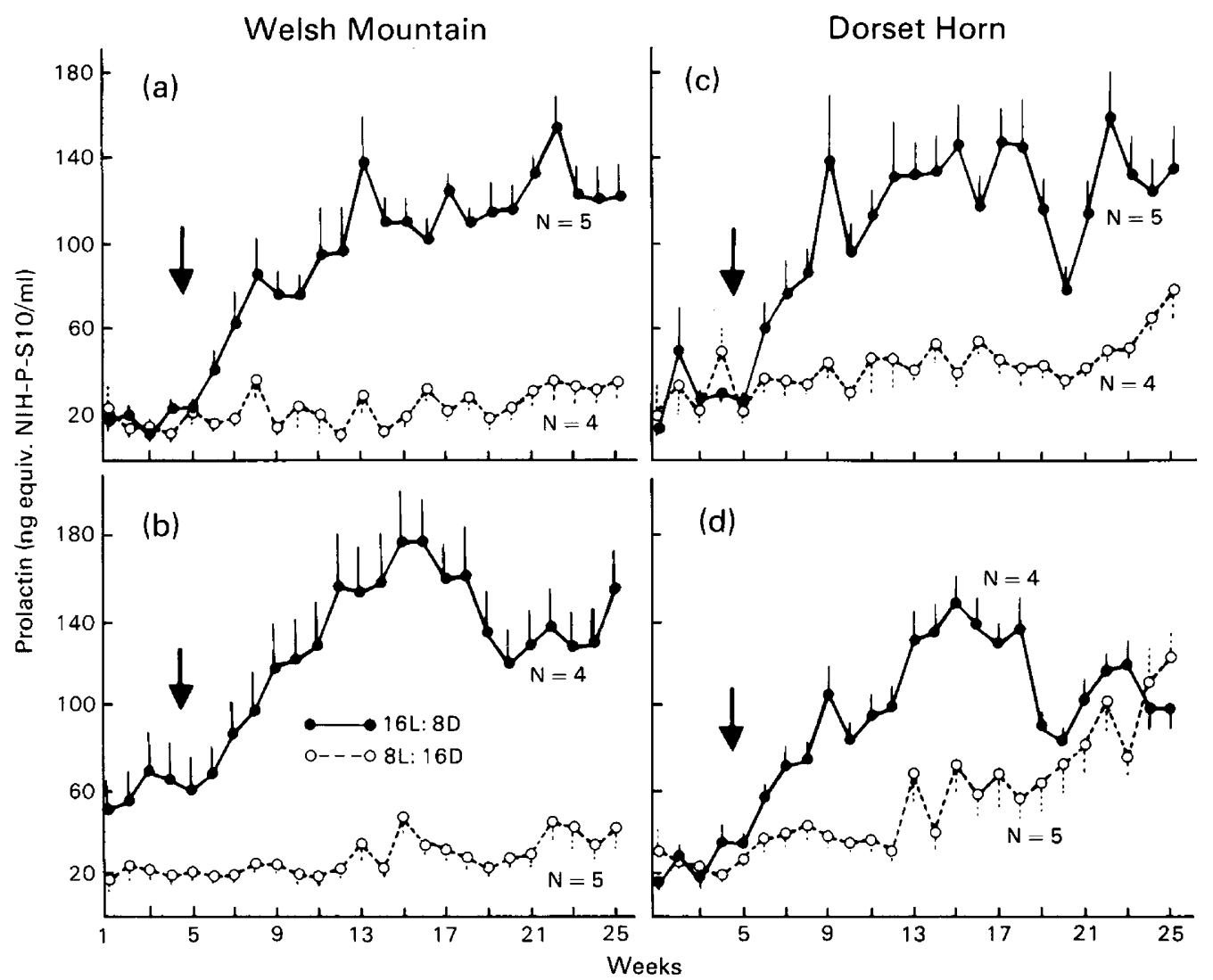

Text-fig. 1. Mean ( \pm s.e.m.) prolactin concentrations in (a) entire Welsh Mountain, (b) oestradiol-treated ovariectomized Welsh Mountain, (c) entire Dorset Horn, and (d) oestradioltreated ovariectomized Dorset Horn ewes maintained in an $8 \mathrm{~L}: 16 \mathrm{D}$ photoperiod or abruptly changed (arrow) to a $16 \mathrm{~L}: 8 \mathrm{D}$ photoperiod in mid-January.

\section{LH concentrations}

LH concentrations in ovariectomized, oestrogen-treated ewes of both breeds were initially high, but then declined slowly from Week 5 or 6 , becoming basal when entire ewes of the same breed became anoestrous (Text-fig. 2). Differences between light treatments in the timing of the onset of 
anoestrus in both breeds are reflected in disparities in the time at which LH levels became basal in ovariectomized, oestrogen-treated ewes. Ewes of both breeds changed to long days stopped cycling earlier and more synchronously than did those maintained in short days; LH patterns in ovariectomized, oestrogen-treated ewes echoed these differences, although the difference in rate of decline in mean LH concentrations was more marked in the Dorset Horn (Text-fig. 2b) than the Welsh Mountain ewes (Text-fig. 2a). Of the animals kept in short days, one representative of each breed was still cyclic at the end of the experiment, while all the entire ewes in long days had become anoestrous. Similarly, in 2 ovariectomized, oestrogen-treated ewes of the Welsh Mountain breed kept in constant short days, LH concentrations remained moderately elevated throughout the experiment, suggesting that these ewes would have been cyclic had they been entire. No such individuals were found amongst the Dorset Horn ewes.

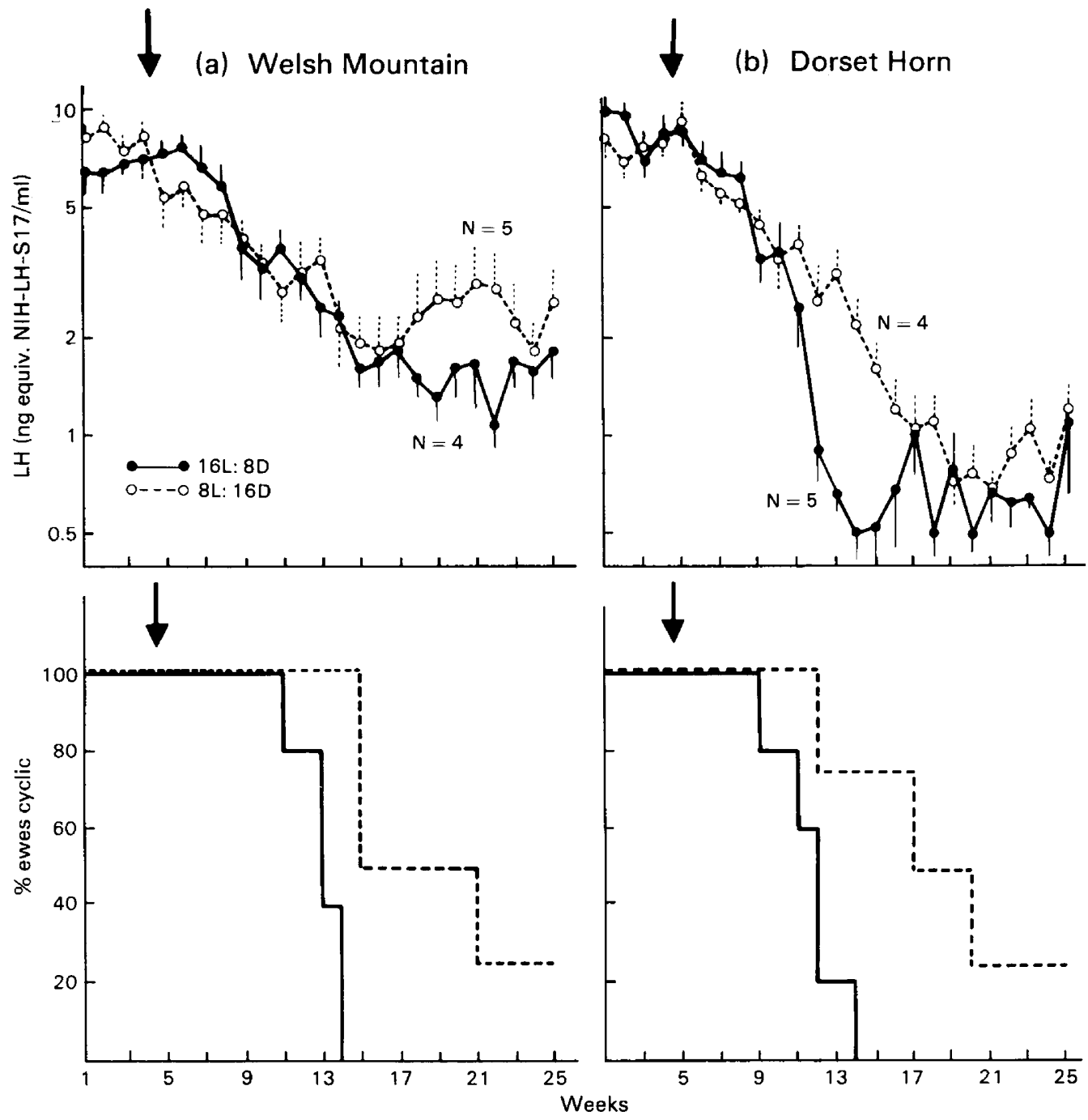

Text-fig. 2. Mean ( \pm s.e.m.) LH concentrations in oestradiol-treated ovariectomized ewes and cyclic activity in entire ewes of (a) the Welsh Mountain and (b) the Dorset Horn breed maintained on an $8 \mathrm{~L}: 16 \mathrm{D}$ photoperiod or abruptly changed (arrow) to a $16 \mathrm{~L}: 8 \mathrm{D}$ photoperiod in mid-January. 


\section{Discussion}

A rapid exposure to long days in mid-winter was successful in significantly advancing the onset of seasonal anoestrus in both breeds, in line with previous findings using other breeds of sheep (Yeates, 1949; Hafez, 1952; Ducker \& Bowman, 1970). This treatment also produced a large and sustained rise in prolactin concentrations, whereas in ewes kept in constant short days prolactin concentrations remained uniformly low. This confirms earlier work on manipulation of prolactin by photoperiod in rams (Pelletier, 1973; Lincoln, McNeilly \& Cameron, 1978) and ewes (Walton, Evins, Fitzgerald \& Cunningham, 1980). Furthermore, the lack of any significant difference in prolactin concentrations between entire and ovariectomized, oestradiol-treated ewes indicates the absence of any involvement of ovarian steroids in the control of prolactin secretion.

These differences in photoperiod-induced changes in prolactin concentrations allowed the possible role of prolactin as a mediator of the seasonal change in negative feedback responses to oestradiol to be examined in ewes of two breeds. If prolactin was fulfilling this role, one would expect the ewes in constant short days to continue to cycle in the absence of the suppressive effect of high concentrations of prolactin. Since this was not the case, it must be concluded that prolactin is not the major vehicle whereby seasonal changes in hypothalamic responsiveness to oestradiol negative feedback are produced, thereby confirming the results of Wright, Findlay \& Anderson (1981b). However, a minor or facilitating role for prolactin cannot be ruled out, since the significant increase in prolactin concentrations induced by an abrupt exposure to long days was associated with a significant advance in the onset of seasonal anoestrus in entire ewes and a decrease in LH concentrations in ovariectomized, oestrogen-treated ewes. In addition, there was considerably more between-ewe variation in both of these indicators in ewes kept in constant short days in which there was no synchronous increase in prolactin concentrations. Indeed, a proportion of the ewes maintained in short days were still 'reproductively active' at the end of the experiment. Further study involving the independent manipulation of daylength and prolactin status is required to determine which component is responsible for these differences.

Mean plasma LH concentrations in ovariectomized, oestrogen-treated ewes declined before the cessation of cyclic activity of entire ewes of the same breed, and this is consistent with previous observations in ewes maintained under conditions of natural photoperiod (Webster \& Haresign, 1983). While this may appear to be incompatible with current concepts of the need for high episode frequency to drive the final stages of follicular growth and maturation (McLeod et al., 1982b) it should be emphasized that it was only when weekly mean concentrations in individual ewes reached basal values $(1-2 \mathrm{ng} / \mathrm{ml})$ that episode frequency would have been insufficient to promote reproductive activity (G. Webster, K. Worthy \& W. Haresign, unpublished data).

It is not clear from the mean LH profiles why the responses in Dorset Horn ewes changed to long days were more pronounced than those of the Welsh Mountain ewes. This may reflect one component of between-breed variation in season length; however, it may merely represent the combined effects of small group sizes together with the within-breed, between-ewe variation in the timing of responses. The mean LH profiles of the Dorset Horn ewes were representative of the changes observed in all ewes within the group. However, while a delayed decline in LH concentrations was observed in 3 of the Welsh Mountain ewes maintained in short days, in the remaining 2 ewes the fall occurred at the same time as the very synchronous decline observed in Welsh Mountain ewes changed to long days.

The fact that maintaining ewes of both breeds in short days did not significantly prolong the breeding season in most cases beyond that found in the same breeds exposed to natural photoperiodic changes (Webster \& Haresign, 1983) may indicate that an endogenous rhythm of breeding activity exists independently of daylength, such that the breeding season can be shifted in time but cannot be materially lengthened. Such rhythms have been demonstrated in ewes maintained in equatorial light regimens (Radford, 1961 b; Wodzicka-Tomaszewska, Hutchinson \& Bennett, 1967; Williams, 1974), in ewes subjected to constant light (Radford, 1961a) and in rams 
maintained in constant photoperiods (Howles et al., 1982), implying that in such circumstances the main importance of daylength is in entraining rather than driving the rhythm.

An alternative interpretation of these data is that ewes of both breeds became insensitive to photic stimulation after prolonged exposure to inductive (short) daylengths. This is consistent with the data of Lincoln \& Short (1980) which illustrated that the seasonal decline in LH concentrations and testis size in Soay rams kept under artificial photoperiods began before the animals were changed to long days. Because the ewes of both breeds maintained in short days in the current study stopped cycling at the same time of year as those subjected to natural photoperiodic changes (Webster \& Haresign, 1983), it may be argued that ewes normally cease to breed because they become photorefractory rather than being driven into anoestrus by inhibitory (long) daylengths. However, an abrupt increase in artificial daylength such as the one involved in the present study can override this normal change and induce premature anoestrus.

The choice of photoperiods used in the current study was based on those used by other workers, and may have masked the underlying causes of between-breed variation in season length. The data obtained by Webster \& Haresign (1983) indicated that, under conditions of natural photoperiodic change, Dorset Horn ewes started to cycle within 5 weeks of the summer solstice whereas Welsh Mountain ewes did not begin to cycle for a further 8-12 weeks. This may therefore represent an inherent breed difference in the response time to the same photoperiodic change or the critical daylength reduction required to 'switch on' reproductive activity. The latter suggestion would certainly be compatible with the natural evolution of the two breeds, since the Dorset Horn breed is descended from the Spanish Merino which evolved in Mediterranean climes while the Welsh Mountain evolved in a more northerly and temperate environment. Future work should therefore be directed towards investigation of these possibilities.

We thank the A.R.C. for financial support and NIH for standard hormone preparations. This work was conducted while $\mathrm{K}$.W. was in receipt of a University of Nottingham Postgraduate Scholarship.

\section{References}

Camper, P.M. \& Burke, W.H. (1977) The effect of prolactin on reproductive function in female Japanese quail (Coturnix coturnix japonica). Poultry Science 65, $1130-1134$.

Carr, W.R. \& Land, R.B. (1982) Seasonal variation in plasma concentrations of prolactin in castrated rams of breeds of sheep with different seasonality of reproduction. J. Reprod. Fert. 66, 231-235.

Ducker, M.J. \& Bowman, J.C. (1970) Photoperiodism in the ewe. 3. The effects of various patterns of increasing daylength on the onset of oestrus in Clun Forest ewes. Anim. Prod. 12, 465-471.

Fang, V.S., Refetoff, S. \& Rosenfield, R.L. (1974) Hypogonadism induced by a transplantable, prolactin-producing tumor in male rats. Hormonal and morphological studies. Endocrinology 95, 991998.

Foster, J.P. \& Crighton, D.B. (1974) Luteinizing hormone $(\mathrm{LH})$ release after single injections of synthetic LH-releasing hormone (LH-RH) in the ewe at three different reproductive stages and comparison with natural LH release at oestrus. Theriogenology 2, 87100.

Hafez, E.S.E. (1952) Studies on the breeding season and reproduction of the ewe. J. agric. Sci., Camb. 42, 189265.
Haresign, W., Foster, J.P., Haynes, N.B., Crighton, D.B. \& Lamming, G.E. (1975) Progesterone levels following treatment of seasonally anoestrous ewes with synthetic LH-releasing hormone. J. Reprod. Fert. 43, 269-279.

Howles, C.M., Webster, G.M. \& Haynes, N.B. (1980) The effect of rearing under a long or short photoperiod on testis growth, plasma testosterone and prolactin concentrations, and the development of sexual behaviour in rams. $J$. Reprod. Fert. 60, 437-447.

Howles, C.M., Craigon, J. \& Haynes, N.B. (1982) Longterm rhythms of testicular volume and plasma prolactin concentrations in rams reared for 3 years in constant photoperiod. J. Reprod. Fert. 65, 439-446.

Kann, G. \& Martinet, J. (1975) Prolactin levels and duration of postpartum anoestrus in lactating ewes. Nature, Lond, 257, 63-64.

Karsch, F.J., Dierschke, D.J., Weick, R.F., Yamaji, T., Hotchkiss, J. \& Knobil, E. (1973) Positive and negative feedback control by estrogen of luteinizing hormone secretion in the rhesus monkey. Endocrinology 92, $799 \cdot 804$.

Legan, S.J. \& Karsch, F.J. (1980) Photoperiodic control of seasonal breeding in ewes: modulation of the negative feedback action of estradiol. Biol. Reprod. 23, $1061-1068$. 
Legan, S.J., Karsch, F.J. \& Foster, D.L. (1977) Endocrine control of seasonal reproductive function in the ewe. Marked changes in the response to the negative feedback effect of estradiol on LH secretion. Endocrinology 101, 818-824.

Lincoln, G.A. \& Short, R.V. (1980) Seasonal breeding: Nature's contraceptive. Recent Prog. Horm. Res. 36, $1-52$.

Lincoln, G.A., McNeilly, A.S. \& Cameron, C.L. (1978) The effects of a sudden decrease or increase in daylength on prolactin secretion in the ram. $J$. Reprod. Fert. 52, 305-311.

McLeod, B.J., Haresign, W. \& Lamming, G.E. (1982a) The induction of ovulation and luteal function in seasonally anoestrous ewes treated with small-dose multiple injections of Gn-RH. J. Reprod. Fert. 65, 215-221.

McLeod, B.J., Haresign, W. \& Lamming, G.E. (1982b) Response of seasonally anoestrous ewes to small dose multiple injections of Gn-RH with and without progesterone pretreatment. J. Reprod. Fert. 65, 223230.

McNeilly, A.S. (1980) Prolactin and the control of gonadotrophin secretion in the female. $J$. Reprod. Fert. 58, 537-549.

McNeilly, A.S., Sharpe, R.M., Davidson, D.W. \& Fraser, H.M. (1978) Inhibition of gonadotrophin secretion by induced hyperprolactinaemia in the male rat. $J$. Endocr. 79, 59-68.

Pelletier, J. (1973) Evidence for photoperiodic control of prolactin release in rams. J. Reprod. Fert. 35, 143147.

Radford, H.M. (1961a) Photoperiodism and sexual activity in Merino ewes. II. The effect of equinoctial light on sexual activity. Aust. J. agric. Res. 12, 147153.
Radford, H.M. (1961b) Photoperiodism and sexual activity in Merino ewes. I. The effect of continuous light on the development of sexual activity. Aust. $J$. agric. Res. 12, 139-146.

Walton, J.S., McNeilly, J.R., McNeilly, A.S. \& Cunningham, F.J. (1977) Changes in concentrations of FSH, $\mathrm{LH}$, prolactin and progesterone in plasma of ewes during the transition from anoestrus to breeding activity. $J$. Endocr. 75, 127-136.

Walton, J.S., Evins, J.D., Fitzgerald, B.P. \& Cunningham, F.J. (1980) Abrupt decrease in daylength and short-term changes in the plasma concentrations of FSH, LH and prolactin in anoestrous ewes. $J$. Reprod. Fert. 59, 163-171.

Webster, G.M. \& Haresign, W. (1983) Seasonal changes in $\mathrm{LH}$ and prolactin concentrations in ewes of two breeds. J. Reprod. Fert. (in press).

Williams, H.L. (1974) The reproductive performance of two British breeds of sheep in contrasting photoperiodic environments. J. agric. Sci., Camb. 82, 377-381.

Wodzicka-Tomaszewska, M., Hutchinson, J.C.D. \& Bennett, N.W. (1967) Control of the annual rhythm of breeding in ewes: effect of an equatorial daylength with reversed thermal seasons. J. agric. Sci., Camb. 68, 61-67.

Wright, P.J., Geytenbeek, P.E., Clarke, I.J. \& Findlay, J.K. (1981a) Evidence for a change in oestradiol negative feedback and LH pulse frequency in postpartum ewes. J. Reprod. Fert. 62, 97-102.

Wright, P.J., Findlay, J.K. \& Anderson, G.A. (1981b) The failure of prolactin to enhance the inhibitory effect of oestradiol-17 $\beta$ on $\mathrm{LH}$ synthesis and release in ewes. $J$. Reprod. Fert. 62, 537-542.

Yeates, N.T.M. (1949) The breeding season of the sheep with particular reference to its modification by artificial means using light. J. agric. Sci., Camb. 39, 143.

Received 16 November 1982 